\title{
PENGUJIAN SECARA IN VIVO EFEKANTIOKSIDATIF DARI EKSTRAK AIR RUMPUT LAUT Sargassum crassifolium
}

\author{
Thamrin Wikanta", Intan K. Rustanti“'), dan Lestari Rahayu“")
}

\begin{abstract}
ABSTRAK
Naskah ini melaporkan hasil uji toksisitas akut $\left(L D_{50}\right)$ dan efek antioksidatif dari ekstrak air rumput laut Sargassum crassifolium. Penentuan $\mathrm{LD}_{50}$ menggunakan metode Weil dengan hewan percobaan mencit (Mus musculus) yang diberikan sediaan secara intraperitoneal (ip). Pada penelitian selanjutnya, digunakan hewan percobaan tikus (Rattus norvegicus L.). Hewan percobaan dibagi menjadi 6 kelompok, yaitu: (K1) kelompok normal, hanya diberi air suling; (K2) kelompok kontrol negatif, seperti kelompok perlakuan tetapi ekstrak air rumput laut diganti air suling; (K3) kelompok perlakuan, diberi ekstrak air rumput laut dosis $0,162 \mathrm{~g} / 100 \mathrm{~g} \mathrm{BB}$; (K4) kelompok perlakuan, diberi ekstrak air rumput laut dosis $0,324 \mathrm{~g} / 100 \mathrm{~g} \mathrm{BB}$; (K5) kelompok perlakuan, diberi ekstrak air rumput laut dosis $0,647 \mathrm{~g} / 100 \mathrm{~g} \mathrm{BB}$; (K6) kelompok kontrol positif, diberi vitamin $E$ dosis $2,7 \mathrm{mg} / 100 \mathrm{~g} \mathrm{BB}$. Kelompok $\mathrm{K} 1$ diperlakukan selama 9 hari percobaan, sedangkan kelompok K2 sampai K6 diperlakukan selama 8 hari. Pada hari ke 8 , dua jam setelah pemberian perlakuan terakhir, Kelompok K2-K6 diberi $\mathrm{CCl}_{4}$ dosis $55,00 \mathrm{mg} / 100 \mathrm{~g} \mathrm{BB}$. 24 jam kemudian dilakukan pengukuran kadar MDA plasma darah dan SOD sel darah merah tikus, dan preparasi sediaan histopatologi hati tikus. Hasil uji toksisitas menunjukkan LD $_{50}$ adalah 194,4 $\mathrm{mg} / 100 \mathrm{~g} \mathrm{BB}$ mencit (ip) atau 13,608 $\mathrm{g} / \mathrm{kg}$ BB tikus (oral). Berdasarkan nilai MDA dan SOD, perlakuan pemberian ekstrak air rumput laut dengan dosis $0,65 \mathrm{~g} / 100 \mathrm{~g}$ BB memiliki efek antioksidan, sedangkan berdasarkan analisis histopatologi hati, pemberian ekstrak air rumput laut dengan dosis $0,324 \mathrm{~g} / 100 \mathrm{~g} \mathrm{BB}$, dapat mencegah kerusakan hati (sebagai hepatoprotektor).
\end{abstract}

\begin{abstract}
In vivo assay on antioxidative effect of Sargassum crassifolium seaweed water extract. By: Thamrin Wikanta, Intan K. Rustanti, and Lestari Rahayu
\end{abstract}

This paper reports the result of acute toxicity test $\left(L D_{50}\right)$ and antioxidative effect of water extract of Sargassum crassifolium seaweed. Measurement of $L D_{50}$ was using Weil method with mouse (Mus musculus) as an experimental animals that given brown seaweed water extract, intraperitoneally (ip). In the extended research, the experimental animal used were rats (Rattus norvegicus L.). Experimental animals were devided into 6 groups: (K1) normal group, only distilled water given; (K2) negative control group, treated as treatment group but seaweed water extract was subtituted with distilled water; $(K 3)$ treatment group, treated with seaweed water extract at the dose of $0.162 \mathrm{~g} / 100 \mathrm{~g} \mathrm{BW} ;(K 4)$ treatment group, treated with seaweed water extract at the dose of $0.324 \mathrm{~g} / 100 \mathrm{~g} \mathrm{BW} ;(K 5)$ treatment group, treated with seaweed water extract at the dose of $0.647 \mathrm{~g} /$ $100 \mathrm{~g} \mathrm{BW}$; (K6) positive control group, treated with vitamin $\mathrm{E}$ at the dose of $2.7 \mathrm{mg} / 100 \mathrm{~g} \mathrm{BW}$. Group $K 1$ was treated for 9 days, while $K 2-K 6$ were treated for 8 days. On the day $8^{\text {th }}$, two hours after last treatment, $\mathrm{CCl}_{4}$ at the dose of $55.00 \mathrm{mg} / 100 \mathrm{~g} \mathrm{BW}$ were given to group K2-K6. Then, 24 hours afterward, rats blood plasma MDA and red blood cell SOD were analyzed, and liver histopathology preparation was made. The acute toxicity test showed that $L D_{50}$ was $194.4 \mathrm{mg} / 100 \mathrm{~g} \mathrm{BW}$ of mice (ip) or $13.608 \mathrm{~g} / \mathrm{kg} \mathrm{BW}$ of rat (oral). Based on the MDA and SOD value, seaweed water extract feeding with dose of $0.65 \mathrm{~g} / 100 \mathrm{~g} \mathrm{BW}$ had an antioxidant effect, while based on the liver histopathology analysis, seaweed water extract feeding with dose of $0.324 \mathrm{~g} / 100 \mathrm{~g} B W$ was able to prevent liver damaged (as a hepatoprotector).

KEYWORDS: water extract, Sargassum crassifolium seaweed, blood plasma, superoxide dismutase, histopathology of rat liver

\section{PENDAHULUAN}

Di masyarakat luas, obat-obatan tradisional makin banyak dipilih karena disamping harganya relatif murah juga dianggap lebih aman dibandingkan dengan obat sintetik. Penerapan obat tradisional perlu dukungan penelitian ilmiah agar penggunaan dan pemanfaatannya dapat dipertanggungjawabkan berdasarkan dosis yang tepat untuk mencegah timbulnya efek samping yang tidak dikehendaki

\footnotetext{
Peneliti pada Balai Besar Riset Pengolahan Produk dan Bioteknologi Kelautan dan Perikanan

*) Fakultas Farmasi - Universitas Pancasila, Jakarta.
} 
Rumput laut mampu memproduksi metabolit primer dan sekunder yang dapat dimanfaatkan untuk berbagai bidang industri. Rumput laut yang terdapat di perairan laut Indonesia memiliki beberapa manfaat dalam industri obat, antara lain sebagai: antihipertensi, anti-bakteri, anti-tumor, anti-oksidasi, antifungi dan anti-hiperkolesterolemia (Suptijah, 2002). Salah satu jenis rumput laut tersebut adalah Sargassum crassifolium. Kandungan metabolit primer pada Sargassum crassifolium yang potensial dan bernilai ekonomis tinggi adalah alginat. Senyawa polisakarida ini banyak digunakan pada berbagai jenis industri, di antaranya pada industri kosmetik dalam pembuatan sabun, krim, lotion, sampo, dan pewarna rambut. Industri farmasi menggunakannya untuk pembuatan suspensi, emulsi, tablet, salep, kapsul, dan lain-lain (Chapman \& Chapman, 1980). Hasil penelitian menunjukkan bahwa natrium alginat berguna sebagai anti-hiperkolesterolemia (Wikanta et al., 2003), sebagai anti-hiperglikemia (Wikanta et al., 2000; Wikanta et al., 2002), sedangkan kalsium alginat berguna sebagai hepatoprotektor (Khotimchenko \& Khotimchenko, 2004). Dalam industri makanan, rumput laut dijadikan sebagai sayur, dan alginat digunakan sebagai bahan tambahan pada industri tekstil, kertas, dan keramik (Atmaja et al., 1996). Penelitian lain mengemukakan bahwa Sargassum crassifolium mengandung golongan senyawa glikosida, saponin, polifenol, tannin, steroid/ triterpenoid. Hasil uji bioaktivitas menunjukkan bahwa ekstrak S. crassifolium memiliki aktivitas sebagai obat gondok, anti-bakteri, dan anti-tumor (Misra et al., 1996).

Jenis rumput laut Sargassum sp. termasuk kelas rumput laut coklat (Phaeophyceae). Rumput laut coklat mengandung senyawa polifenol yang memiliki beberapa fungsi antara lain menghambat pertumbuhan mikroba dan menyerap sinar radiasi ultra-violet yang berbahaya bagi kesehatan. Secara umum senyawa polifenol bersifat dapat meredam radikal bebas atau sebagai anti-oksidan, baik melalui delokalisasi elektron dan membentuk ikatan hidrogen intramolekuler maupun melalui penataan kembali struktur molekulnya. Polifenol juga akan membentuk chelate dengan ion tembaga dan besi bebas, ion-ion yang mengkatalisis pembentukan senyawa oksigen reaktif yang dapat memicu pembentukan radikal bebas (Dadan, 2001; Jansen, 2002). Tumor merupakan penyakit yang dipicu oleh adanya kerusakan sel dan organel dalam tubuh, di antaranya adalah karena serangan radikal bebas, maka untuk menetralkan dan menghancurkan radikal bebas diperlukan anti-oksidan. Sesungguhnya, di dalam tubuh manusia terbentuk anti-oksidan dalam jumlah terbatas yang berperan untuk menetralkan sejumlah radikal bebas yang terbentuk. A pabila radikal bebas yang terbentuk di dalam tubuh jumlahnya terbatas sehingga dapat dinetralkan oleh sistem tubuh maka tidak menjadi masalah dalam kesehatan. Akan tetapi, apabila masukan radikal bebas ke dalam tubuh jumlahnya sangat banyak, maka diperlukan antioksidan tambahan dari luar (anti-oksidan eksogen), seperti: vitamin E, vitamin $C$, dan bahan makanan lain yang dapat meningkatkan daya tahan tubuh dari serangan radikal bebas.

Kerusakan membran sel oleh radikal bebas dapat diketahui dengan mengukur kadar malondialdehida (MDA), hasil reaksi peroksidasi lipid oleh radikal bebas. Selain itu dapat juga dengan mengukur kadar superoksida dismutase (SOD), enzim yang berperan dalam sistem pertahanan tubuh untuk mengatasi kelebihan pembentukan radikal bebas. Enzim SOD banyak ditemukan pada eritrosit yang dapat mengubah radikal bebas superoksida yang toksik menjadi $\mathrm{H}_{2} \mathrm{O}_{2}$ yang kurang toksik (Franciscus, 1989). Selain itu, kerusakan sel dapat dilihat dari gambaran histopatologi hati tikus.

Pada penelitian ini akan diamati efek anti-oksidan dari ekstrak air Sargassum crassifolium melalui pengukuran kadar MDA plasma darah dan SOD sel darah merah, serta gambaran histopatologi hati tikus yang telah diinduksi karbon tetraklorida $\left(\mathrm{CCl}_{4}\right)$. Karbon tetraklorida digunakan sebagai pembentuk radikal bebas yang dalam dosis kecil dapat menimbulkan efek pada berbagai organ tubuh.

\section{BAHAN DAN METODE}

\section{Bahan}

Sediaan uji yang akan diteliti adalah ekstrak air rumput laut Sargassum crassifolium, hasil panen dari pantai Binuangeun, Banten Selatan, pada bulan Juli 2003.

\section{Hewan percobaan}

Hewan percobaan yang digunakan pada penentuan toksisitas akut adalah mencit putih (Mus musculus), dan pada penelitian selanjutnya digunakan tikus putih (Rattus norvegicus L.) galur Wistar, jenis kelamin jantan, bobot badan (BB) antara 150-200 gram, umur 2-3 bulan, sebanyak 30 ekor. Seluruh tikus dipelihara selama 1 minggu untuk penyesuaian lingkungan, mengontrol kesehatan dan berat badan, serta menyeragamkan makanan. Makanan yang digunakan adalah makanan standar. Tikus ditempatkan di dalam kandang, satu ekor tikus per kandang. Tikus dan makanan standar diperoleh dari Unit Pemeliharaan 
Hewan, Pusat Penelitian dan Pengembangan Kesehatan, Departemen Kesehatan, Jakarta.

\section{Metode}

\section{Penentuan toksisitas akut $\left(\mathrm{LD}_{50}\right)$}

Untuk menentukan dosis yang akan digunakan pada percobaan, terlebih dahulu dilakukan penentuan toksisitas akut $\left(\mathrm{LD}_{50}\right)$ berdasarkan metode Weil (Harmita dan Radji, 2004), menggunakan hewan percobaan mencit putih, jenis kelamin jantan. Pemberian sediaan dilakukan secara intraperitoneal (ip), dan jumlah kematian mencit dihitung setelah 24 jam. Perhitungan nilai $L_{50}$ dilakukan berdasarkan tabel biometrik dari Weil (1952). Nilai $\mathrm{LD}_{50}$ untuk tikus putih (Rattus norvegicus L.) dihitung berdasarkan nilai $\mathrm{LD}_{50}$ dari mencit dikalikan faktor konversi sesuai dengan nilai pada tabel yang tersedia.

\section{Pelaksanaan percobaan}

Pada penelitian selanjutnya digunakan tikus putih (Rattus norvegicus L.) sebanyak 30 ekor. Seluruh tikus dibagi menjadi 6 kelompok, masing-masing terdiri dari 5 ekor, yaitu:

K1: kelompok kontrol normal, hanya diberikan air suling, dan pada hari ke- 9 tikus dimatikan, lalu dibedah.

K2: kelompok kontrol negatif, diberikan air suling selama 8 hari, 2 jam setelah pemberian air suling terakhir lalu diberi $\mathrm{CCl}_{4}$ per oral, dosis $55,00 \mathrm{mg} /$ $100 \mathrm{~g} \mathrm{BB}$, dan pada hari ke-9 tikus dimatikan, lalu dibedah.

K3: kelompok perlakuan, diberi ekstrak air rumput laut per oral, dosis $0,162 \mathrm{~g} / 100 \mathrm{~g}$ BB selama 8 hari, 2 jam setelah pemberian ekstrak air terakhir lalu diberi $\mathrm{CCl}_{4}$ per oral, dosis $55,00 \mathrm{mg} / 100 \mathrm{~g}$ $\mathrm{BB}$, dan pada hari ke- 9 tikus dimatikan, lalu dibedah.

K4: kelompok perlakuan, diberi ekstrak air rumput laut per oral, dosis $0,324 \mathrm{~g} / 100 \mathrm{~g}$ BB selama 8 hari, 2 jam setelah pemberian ekstrak air terakhir lalu diberi $\mathrm{CCl}_{4}$ per oral, dosis $55,00 \mathrm{mg} / 100 \mathrm{~g}$ $\mathrm{BB}$, dan pada hari ke- 9 tikus dimatikan, lalu dibedah.

K5: kelompok perlakuan, diberi ekstrak air rumput laut per oral, dosis $0,647 \mathrm{~g} / 100 \mathrm{~g}$ BB selama 8 hari, 2 jam setelah pemberian ekstrak air terakhir lalu diberi $\mathrm{CCl}_{4}$ per oral, dosis $55,00 \mathrm{mg} / 100 \mathrm{~g}$ $\mathrm{BB}$, dan pada hari ke- 9 tikus dimatikan, lalu dibedah.

K6: kelompok kontrol positif, diberi vitamin $E$, dosis $2,7 \mathrm{mg} / 100 \mathrm{~g}$ BB selama 8 hari, 2 jam setelah pemberian vitamin $\mathrm{E}$ lalu diberi $\mathrm{CCl}_{4}$ per oral, dosis $55,00 \mathrm{mg} / 100 \mathrm{~g} \mathrm{BB}$, dan pada hari ke-9 tikus dimatikan, lalu dibedah.

\section{Pemeriksaan histopatologi}

Pemeriksaan histopatologi pada penelitian ini digunakan metode pemeriksaan histopatologi biasa dengan tahap proses pembuatan sediaan secara singkat, sebagai berikut: (1) pencucian dan perendaman organ dalam $\mathrm{NaCl} 0,9 \%$ lalu dipotongpotong dan difiksasi dalam larutan Bouin; (2) dehidrasi dalam alkohol, lalu perendaman dalam benzil benzoat sampai transparan, kemudian perendaman dalam benzol; (3) perendaman dalam parafin cair; (4) penyayatan (sectioning) dengan mikrotom; (5) penempelan (mounting) pada gelas obyek; (6) deparafinisasi dengan perendaman dalam xilol; (7) hidrasi dan penghilangan xilol melalui perendaman dalam alkohol dengan seri konsentrasi menurun; (8) pewarnaan (staining) dengan larutan hematoksilineosin; (9) dehidrasi melalui perendaman dalam alkohol dengan seri konsentrasi meningkat; (10) penjernihan melalui perendaman dalam larutan xilol; (11) setelah pembersihan lalu penutupan dengan kaca penutup, lalu dibiarkan kering pada suhu kamar (Suntoro, 1983).

\section{HASIL DAN BAHASAN}

\section{Toksisitas Akut (LD ${ }_{50}$ ) Ekstrak Air Rumput Laut S. crassifolium}

Penentuan toksisitas akut $\left(\mathrm{LD}_{50}\right)$ adalah untuk menentukan nilai batas keamanan penggunaan ekstrak air rumput laut S. crassifolium. Hasil penentuan nilai $\mathrm{LD}_{50}$ dengan menggunakan metode Weil (Harmita \& Radji, 2004) didapatkan nilai LD $_{50}$ ekstrak air rumput laut $S$. crassifolium adalah 194,4 $\mathrm{mg} / 100 \mathrm{~g}$ BB mencit (Mus musculus) (ip). Pada penelitian selanjutnya, hewan percobaan yang digunakan adalah tikus (Rattus norvegicus L.), maka nilai $L_{50}$ yang didapatkan dari mencit harus dikalikan faktor pengali sesuai tabel konversi, sehingga didapatkan nilai $1,3608 \mathrm{~g} / 100 \mathrm{~g}(13,608 \mathrm{~g} / \mathrm{kg})$ BB tikus (oral). Menurut klasifikasi dari Gleason (1969), nilai $\mathrm{LD}_{50}$ sebesar $5-15 \mathrm{~g} / \mathrm{kg}$ BB termasuk dalam bahan dengan toksisitas rendah (Harmita \& Radji, 2004). Hal tersebut menunjukkan bahwa ekstrak air rumput laut S. crasifolium termasuk kelompok bahan dengan toksisitas rendah. Hasil perhitungan dosis menghasilkan nilai batas atas $16,180 \mathrm{~g} / \mathrm{kg}$ BB dan batas bawah 11,445 g/kg BB.

\section{Kadar Malondialdehida (MDA) Plasma}

Untuk mengetahui sifat antioksidan ekstrak air rumput laut $\mathrm{S}$. crassifolium, digunakan larutan $\mathrm{CCl}_{4}$ 
sebagai pembentuk radikal bebas. Larutan $\mathrm{CCl}_{4}$ yang diberikan secara oral kepada tikus, setelah masuk ke dalam saluran cerna akan diabsorpsi ke dalam aliran darah menuju ke hati melalui vena porta, selanjutnya dalam hati akan dimetabolisme menjadi radikal triklorometil $\left(\mathrm{CCl}_{3}{ }^{*}\right)$ pada retikulum endoplasma. Dengan adanya oksigen maka bentuk radikal $\mathrm{CCl}_{3}{ }^{*}$ akan diubah menjadi radikal triklorometildioksida $\left(\mathrm{CCl}_{3} \mathrm{O}_{2}{ }^{*}\right)$ yang bersifat lebih reaktif. Bentuk radikal tersebut akan bereaksi dengan asam lemak tak jenuh pada membran sel membentuk peroksida lipid. Akibat dari peroksidasi lipid membran maka akan terjadi perubahan fluiditas, struktur, dan fungsi membran yang menimbulkan kerusakan sel, dan bahkan dapat mengakibatkan kematian sel. Kerusakan sel akibat peroksidasi lipid tersebut dianggap sebagai salah satu penyebab berbagai penyakit degeneratif atau kemerosotan fungsi tubuh. Kerusakan sel akibat radikal bebas dapat dilihat melalui adanya peningkatan kadar malondialdehida (MDA) plasma darah, karena MDA adalah produk peroksidasi lipid dari asam lemak tak jenuh oleh radikal bebas.

Hasil pengukuran kadar MDA terlihat pada Gambar 1. Hasil uji kenormalan dan homogenitas data MDA yang diperoleh menunjukkan data normal dan homogen selanjutnya data dianalisis dengan statistik parametrik menggunakan metode anova satu arah. Hasil analisis statistik anova satu arah menunjukkan bahwa ada perbedaan bermakna antar kelompok perlakuan, maka analisis dilanjutkan dengan uji beda nyata terkecil (BNT) dengan $\alpha=5 \%$.

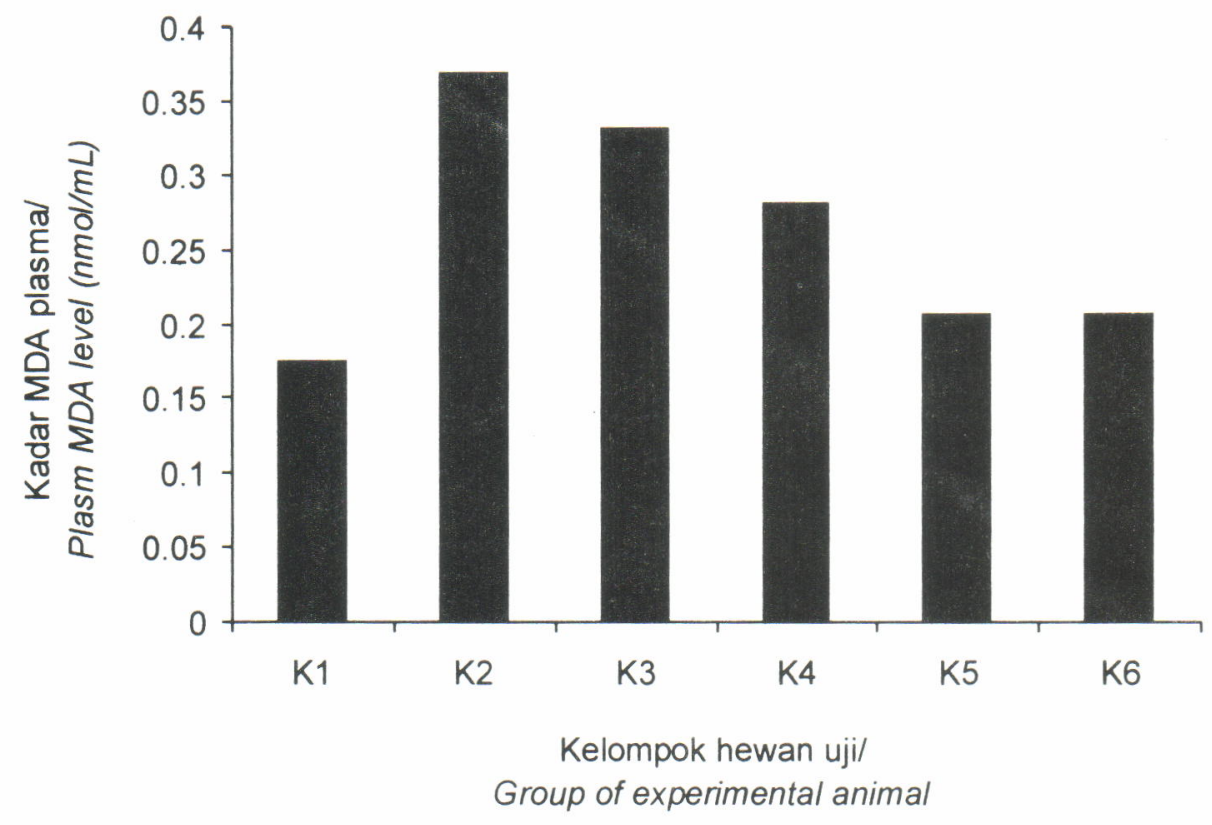

Gambar 1. Kadar MDA plasma darah dari setiap kelompok percobaan. Figure 1. Blood plasm MDA level of each treatment group.

Catatan/Note:

K1 : Kelompok kontrol normal/Normal control group

K2 : Kelompok kontrol negatif, diberi air suling dan $\mathrm{CCl}_{4} 55,00 \mathrm{mg} / 100 \mathrm{~g} \mathrm{BB} .1$ Negative control group, given distilled water and $\mathrm{CCl}_{4} 55.00 \mathrm{mg} / 100 \mathrm{~g} \mathrm{BW}$

K3 : Kelompok yang diberi ekstrak air rumput laut dosis $0,162 \mathrm{~g} / 100 \mathrm{~g} \mathrm{BB}$ dan $\mathrm{CCl}_{4} 55,00 \mathrm{mg} / 100 \mathrm{~g} \mathrm{BB} .1$ Group was given seaweed water extract with the dose of $0.162 \mathrm{~g} / 100 \mathrm{~g} \mathrm{BW}$ and $\mathrm{CCl}_{4} 55.00 \mathrm{mg} / 100 \mathrm{~g} \mathrm{BW}$

K4 : Kelompok yang diberi ekstrak air rumput laut dosis $0,324 \mathrm{~g} / 100 \mathrm{~g} \mathrm{BB}$ dan $\mathrm{CCl}_{4} 55,00 \mathrm{mg} / 100 \mathrm{~g} \mathrm{BB}$. I Group was given seaweed water extract with the dose of $0.324 \mathrm{~g} / 100 \mathrm{~g} \mathrm{BW}$ and $\mathrm{CCl}_{4} 55.00 \mathrm{mg} / 100 \mathrm{~g} \mathrm{BW}$

K5 : Kelompok yang diberi ekstrak air rumput laut dosis $0,647 \mathrm{~g} / 100 \mathrm{~g} \mathrm{BB}$ dan $\mathrm{CCl}_{4} 55,00 \mathrm{mg} / 100 \mathrm{~g} \mathrm{BB}$.I Group was given seaweed water extract with the dose of $0.647 \mathrm{~g} / 100 \mathrm{~g} \mathrm{BW}$ and $\mathrm{CCl}_{4} 55.00 \mathrm{mg} / 100 \mathrm{~g} \mathrm{BW}$

K6 : Kelompok kontrol positif, diberi vitamin-E 2,7 mg/100 BB dan $\mathrm{CCl}_{4} 55,00 \mathrm{mg} / 100 \mathrm{~g}$ BB.I Positive control group was given vitamin-E $2.7 \mathrm{mg} / 100 \mathrm{~g} \mathrm{BW}$ and $\mathrm{CCl}_{4} 55.00 \mathrm{mg} / 100 \mathrm{~g} \mathrm{BW}$ 
Terjadinya kenaikan MDA plasma pada kelompok $\mathrm{K} 2$ (kontrol negatif), $\mathrm{K} 3, \mathrm{~K} 4, \mathrm{~K} 5$, dan $\mathrm{K} 6$ dibanding kelompok K1 (kontrol normal) menunjukkan terjadinya peroksidasi lipid. Pemberian ekstrak air rumput laut S. crassifolium pada kelompok K3, K4, dan K5 menunjukkan adanya penurunan kadar MDA, yang berarti aktivitas peroksidasi dapat diredam. Makin tinggi pemberian dosis ekstrak air rumput laut maka kadar MDA makin menurun berarti aktivitas atau efektifitas peredaman radikal bebas makin meningkat. Dari hasil kadar MDA antara kelompok K2, K3, K4, $\mathrm{K} 5$, dan $\mathrm{K} 6$ dengan kelompok $\mathrm{K} 1$ (kontrol normal) menunjukkan bahwa secara statistik kelompok K5 dan $\mathrm{K} 6$ tidak berbeda nyata dengan kelompok $\mathrm{K} 1$, berarti ekstrak air rumput laut $S$. crassifolium dosis $0,647 \mathrm{~g} / 100 \mathrm{~g}$ BB dan vitamin $E$ dosis $2,7 \mathrm{mg} / 100 \mathrm{~g}$ BB dapat berperan sebagai antioksidan yang efektif. Perbandingan antara kadar MDA pada kelompok K3,
K4, dan K5 dengan kelompok K6 (kontrol positif) menunjukkan bahwa secara statistik kelompok K5 dan $\mathrm{K} 6$ tidak berbeda nyata. Hal ini berarti bahwa ekstrak air rumput laut $S$. crassifolium dosis $0,647 \mathrm{~g} /$ $100 \mathrm{~g}$ BB tikus memiliki efektivitas sebagai antioksidan sama kuat dengan vitamin $E$ dosis $2,7 \mathrm{mg} / 100 \mathrm{~g}$ BB tikus.

\section{Kadar Superoksida Dismutase (SOD) Sel Darah Merah}

Kerusakan sel akibat radikal bebas dapat juga dilihat melalui penurunan kadar enzim superoksida dismutase (SOD) eritrosit. Enzim SOD diproduksi tubuh (antioksidan endogen) untuk menetralkan dan mengatasi hasil reaksi akibat timbulnya radikal bebas. Pada kondisi kerusakan hati yang parah atau adanya asupan radikal bebas yang berlebihan ke dalam tubuh

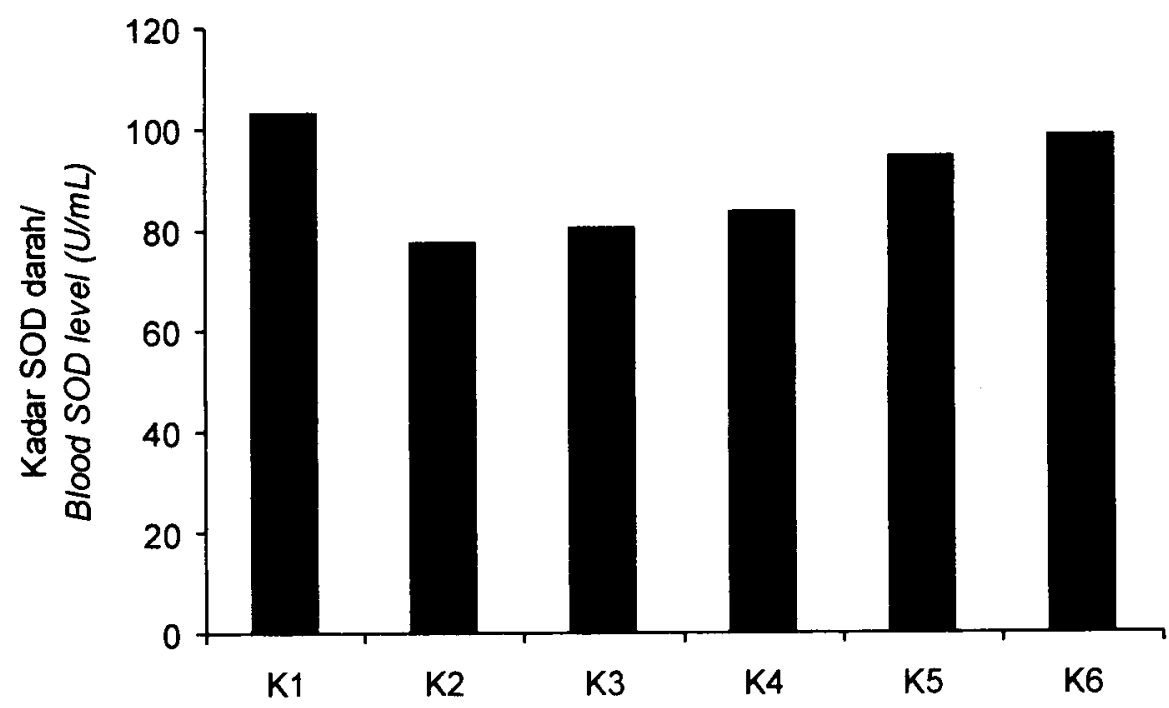

Kelompok hewan uji/Group of experimental animal

Gambar 2. Kadar SOD sel darah merah hewan percobaan.

Figure 2. Red blood cell SOD level of experimental animal.

Catatan/Note:

K1 : Kelompok kontrol normal/Normal control group

K2 : Kelompok kontrol negatif, diberi air suling dan $\mathrm{CCl}_{4} 55,00 \mathrm{mg} / 100 \mathrm{~g} \mathrm{BB} . /$ Negative control group, given distilled water and $\mathrm{CCl}_{4} 55.00 \mathrm{mg} / 100 \mathrm{~g} \mathrm{BW}$.

K3 : Kelompok yang diberi ekstrak air rumput laut dosis $0,162 \mathrm{~g} / 100 \mathrm{~g} \mathrm{BB}$ dan $\mathrm{CCl}_{4} 55,00 \mathrm{mg} / 100 \mathrm{~g} \mathrm{BB} . /$ Group was given seaweed water extract with the dose of $0.162 \mathrm{~g} / 100 \mathrm{~g} \mathrm{BW}$ and $\mathrm{CCl}_{4} 55.00 \mathrm{mg} / 100 \mathrm{~g} \mathrm{BW}$

K4 : Kelompok yang diberi ekstrak air rumput laut dosis $0,324 \mathrm{~g} / 100 \mathrm{~g} \mathrm{BB}$ dan $\mathrm{CCl}_{4} 55,00 \mathrm{mg} / 100 \mathrm{~g} \mathrm{BB} . /$ Group was given seaweed water extract with the dose of $0.324 \mathrm{~g} / 100 \mathrm{~g} \mathrm{BW}$ and $\mathrm{CCl}_{4} 55.00 \mathrm{mg} / 100 \mathrm{~g} \mathrm{BW}$

K5 : Kelompok yang diberi ekstrak air rumput laut dosis $0,647 \mathrm{~g} / 100 \mathrm{~g} \mathrm{BB}$ dan $\mathrm{CCl}_{4} 55,00 \mathrm{mg} / 100 \mathrm{~g} \mathrm{BB} . /$ Group was given seaweed water extract with the dose of $0.647 \mathrm{~g} / 100 \mathrm{~g} \mathrm{BW}$ and $\mathrm{CCl}_{4} 55.00 \mathrm{mg} / 100 \mathrm{~g} \mathrm{BW}$

K6 : Kelompok kontrol positif, diberi vitamin-E 2,7 mg/100 BB dan $\mathrm{CCl}_{4} 55,00 \mathrm{mg} / 100 \mathrm{~g} \mathrm{BB} . /$ Positive control group was given vitamin-E $2.7 \mathrm{mg} / 100 \mathrm{~g} \mathrm{BW}$ and $\mathrm{CCl}_{4} 55.00 \mathrm{mg} / 100 \mathrm{~g} \mathrm{BW}$ 
maka jumlah enzim SOD yang tersedia tak cukup untuk memenuhi kebutuhan tubuh sehingga perlu adanya asupan antioksidan dari luar (antioksidan eksogen) untuk menetralkan radikal bebas yang ada. Upaya penggunaan ekstrak air rumput laut $S$. crassifolium diharapkan dapat bermanfaat untuk menetralkan radikal bebas yang terbentuk di dalam tubuh dan sangat merusak sel tubuh karena dapat menimbulkan berbagai jenis penyakit degeneratif.

Hasil pengukuran kadar SOD terlihat pada Gambar 2. Hasil uji kenormalan dan homogenitas data SOD yang diperoleh menunjukkan data normal dan homogen. Selanjutnya data dianalisis dengan statistik parametrik menggunakan metode anova satu arah. Hasil analisis statistik anova satu arah menunjukkan bahwa ada perbedaan bermakna antar kelompok perlakuan, maka analisis dilanjutkan dengan uji beda nyata terkecil (BNT) dengan $\alpha=5 \%$.
Kelompok K2 (kontrol negatif) memiliki SOD yang rendah karena enzim banyak digunakan untuk menetralkan radikal bebas. Pada kelompok K3, K4, dan K5 (perlakuan ekstrak air rumput laut) menunjukkan kadar SOD yang semakin meningkat dengan meningkatnya pemberian dosis ekstrak. Hal ini berarti peningkatan dosis ekstrak dapat meningkatkan kemampuan sel darah merah meredam radikal bebas yang terdapat dalam tubuh. Membandingkan kadar SOD pada kelompok K2 (kontrol negatif), K3, K4, K5, dan K6 (kontrol positif) dengan kelompok K1 (kontrol normal) menunjukkan bahwa secara statistik kelompok K6 tidak berbeda nyata dengan kelompok $\mathrm{K} 1$, hal ini berarti bahwa kelompok $\mathrm{K} 6$ berperan sebagai antioksidan yang efektif. Membandingkan kadar SOD antara kelompok $\mathrm{K} 3, \mathrm{~K} 4$, dan $\mathrm{K} 5$ dengan $\mathrm{K} 6$ menunjukkan bahwa kelompok $\mathrm{K} 5$ dan $\mathrm{K} 6$ secara statistik tidak berbeda nyata, berarti kelompok $\mathrm{K} 5$ dan $\mathrm{K} 6$ memiliki sifat

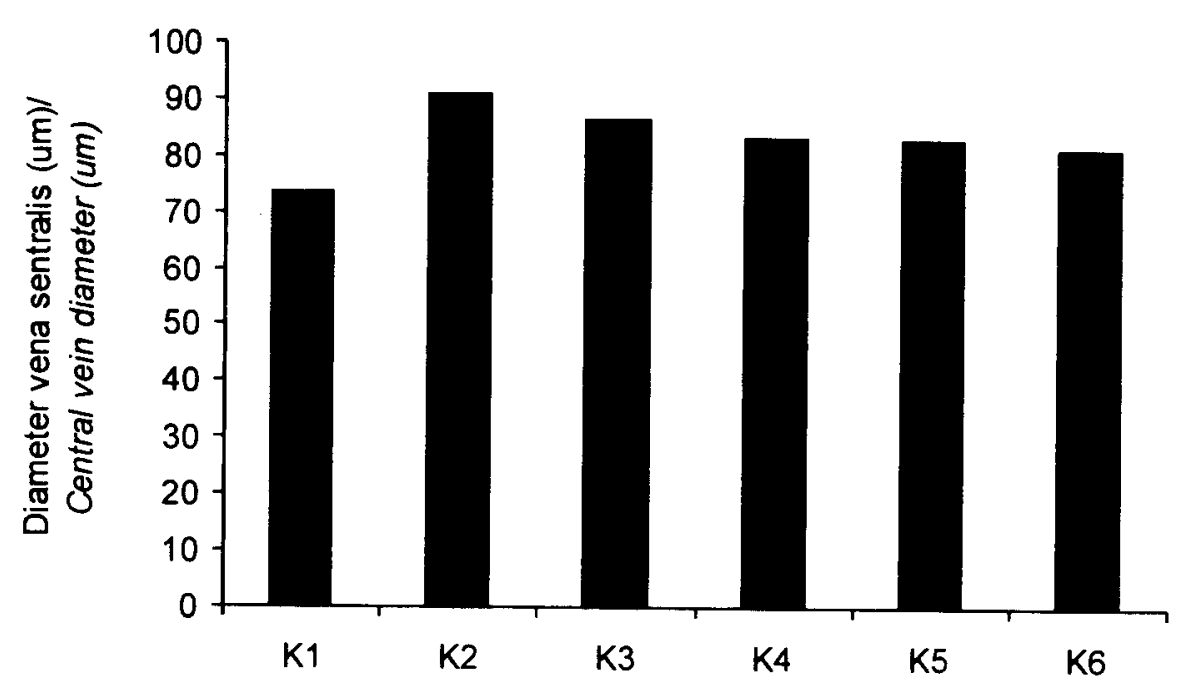

Kelompok hewan uji/Group of experimental animal

Gambar 3. Diameter rata-rata vena sentralis $(\mu \mathrm{m})$.

Figure 3. Mean diameter of central vein $(\mu \mathrm{m})$.

\section{Catatan/Note}

K1 : Kelompok kontrol normal/Normal control group

K2 : Kelompok kontrol negatif, diberi air suling dan $\mathrm{CCl}_{4} 55,00 \mathrm{mg} / 100 \mathrm{~g} \mathrm{BB} . \mathrm{I}$ Negative control group, given distilled water and $\mathrm{CCl}_{4} 55.00 \mathrm{mg} / 100 \mathrm{~g} \mathrm{BW}$.

K3 : Kelompok yang diberi ekstrak air rumput laut dosis $0,162 \mathrm{~g} / 100 \mathrm{~g} \mathrm{BB}$ dan $\mathrm{CCl}_{4} 55,00 \mathrm{mg} / 100 \mathrm{~g} \mathrm{BB} . /$ Group was given seaweed water extract with the dose of $0.162 \mathrm{~g} / 100 \mathrm{~g} \mathrm{BW}$ and $\mathrm{CCl}_{4} 55.00 \mathrm{mg} / 100 \mathrm{~g} \mathrm{BW}$

K4 : Kelompok yang diberi ekstrak air rumput laut dosis $0,324 \mathrm{~g} / 100 \mathrm{~g} \mathrm{BB}$ dan $\mathrm{CCl}_{4} 55,00 \mathrm{mg} / 100 \mathrm{~g} \mathrm{BB} . /$ Group was given seaweed water extract with the dose of $0.324 \mathrm{~g} / 100 \mathrm{~g} \mathrm{BW}$ and $\mathrm{CCl}_{4} 55.00 \mathrm{mg} / 100 \mathrm{~g} \mathrm{BW}$

K5 : Kelompok yang diberi ekstrak air rumput laut dosis $0,647 \mathrm{~g} / 100 \mathrm{~g} \mathrm{BB}$ dan $\mathrm{CCl}_{4} 55,00 \mathrm{mg} / 100 \mathrm{~g} \mathrm{BB}$.I Group was given seaweed water extract with the dose of $0.647 \mathrm{~g} / 100 \mathrm{~g} \mathrm{BW}$ and $\mathrm{CCl}_{4} 55.00 \mathrm{mg} / 100 \mathrm{~g} \mathrm{BW}$

K6 : Kelompok kontrol positif, diberi vitamin-E 2,7 mg/100 BB dan $\mathrm{CCl}_{4} 55,00 \mathrm{mg} / 100 \mathrm{~g} \mathrm{BB}_{4}$. Positive control group was given vitamin-E $2.7 \mathrm{mg} / 100 \mathrm{~g} \mathrm{BW}$ and $\mathrm{CCl}_{4} 55.00 \mathrm{mg} / 100 \mathrm{~g} \mathrm{BW}$ 
antioksidan sama kuat sebagai penangkap radikal bebas.

\section{Pemeriksaan Histopatologi Hati}

Hati merupakan pusat metabolisme lemak, karbohidrat dan protein. Di dalam hati terjadi detoksifikasi obat dan bahan-bahan lain yang bersifat racun bagi tubuh, dan terjadinya proses produksi zatzat penting bagi tubuh, misalnya: zat untuk koagulasi darah, metabolisme besi, pembentukan dan pemecahan hemoglobin, dan produksi empedu yang membantu proses absorpsi lemak dan vitamin larut lemak dari saluran cerna ke dalam darah. Histopatologi adalah pemeriksaan morfologi sel atau jaringan pada sediaan mikroskopik untuk menetapkan diagnosis kelainan, radang, atau infeksi. Kerusakan sel akibat serangan radikal bebas dapat juga dilihat melalui gambaran histopatologi hati.

\section{Diameter vena sentralis}

Hasil pengukuran diameter vena sentralis terlihat pada Gambar 3. Hasil uji kenormalan dan homogenitas data diameter vena sentralis yang diperoleh menunjukkan data normal dan homogen. Selanjutnya data dianalisis dengan statistik parametrik menggunakan metode anova satu arah. Hasil analisis statistik anova satu arah menunjukkan bahwa ada perbedaan bermakna antar kelompok perlakuan, maka analisis dilanjutkan dengan uji beda nyata terkecil (BNT) dengan $\mathrm{a}=5 \%$.
Diameter vena sentralis pada kelompok K2 (kontrol negatif) memiliki nilai tinggi karena terjadinya kerusakan pada sel hati oleh radikal bebas yang terbentuk. Membandingkan kelompok perlakuan K3, K4, K5, dan K6 (kontrol positif) dengan kelompok K2 (kontrol negatif) terlihat adanya penurunan diameter vena sentralis karena adanya pemberian zat yang berperan sebagai antioksidan, penangkap radikal bebas. Hal ini menunjukkan terjadinya perbaikan sel hati yang mengalami kerusakan akibat radikal bebas yang terbentuk. Makin tinggi dosis ekstrak rumput laut $S$. crassifolium yang diberikan, perbaikan sel hati makin meningkat. Antara kelompok K1 dan K6 secara statistik tak ada perbedaan yang nyata, menunjukkan bahwa vitamin $E$ dosis $2,7 \mathrm{mg} / 100 \mathrm{~g}$ BB bersifat efektif sebagai antioksidan yang dapat mencegah kerusakan sel hati akibat induksi $\mathrm{CCl}_{4}$ dosis $0,55 \mathrm{mg} / \mathrm{g} \mathrm{BB}$.

Antara kelompok $\mathrm{K} 4, \mathrm{~K} 5$, dan $\mathrm{K} 6$ yang secara statistik tidak berbeda nyata menunjukkan bahwa ekstrak air rumput laut dosis $0,324 \mathrm{~g} / 100 \mathrm{~g} \mathrm{BB}$ dan $0,647 \mathrm{~g} / 100 \mathrm{~g} \mathrm{BB}$ memiliki efektivitas sebagai antioksidan yang sama kuat dengan vitamin $\mathrm{E}$ dosis $2,7 \mathrm{mg} / 100 \mathrm{~g} \mathrm{BB}$.

\section{Gambaran histopatologi hati}

Pengamatan mengenai gambaran histopatologi hati pada 6 kelompok hewan percobaan menunjukkan hasil seperti terlihat pada Gambar 4, 5, 6, 7, 8, dan 9 .

Hasil analisis gambaran histopatologi hati menunjukkan bahwa kelompok K2 (kontrol negatif)

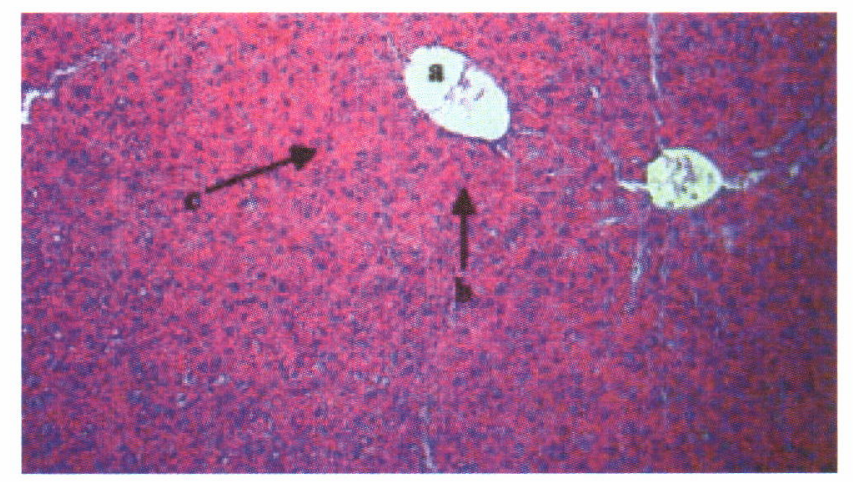

Gambar 4. Histopatologi hati tikus kelompok K1 (kontrol normal).

a. Diameter vena sentralis,

b. Sel endotel vena sentralis,

c. Hepatosit.

Figure 4. Histopathology of rat liver group K1 (normal control).

a. Diameter of central vein,

b. Endothel cell of central vein,

c. Hepatocyt. 


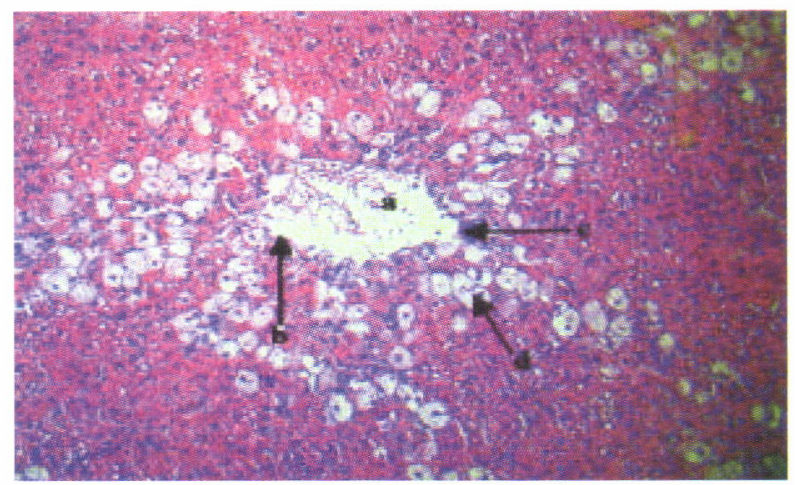

Gambar 5. Histopatologi hati tikus kelompok K2 (kontrol negatif $\mathrm{CCl}_{4} 55,00$ mg/100 g BB).
a. Diameter vena sentralis,
b. Sel endotel vena sentralis,
c. Ada penumpukan sel darah putih.
d. Hepatosit.

Figure 5. Histopathology of rat liver group K2 (negative control $\mathrm{CCl}_{4} 55.00 \mathrm{mg} / 100 \mathrm{~g} \mathrm{BW}$ ).
a. Diameter of central vein,
b. Endothel cell of central vein,
c. There was a gathering of leucocyt.
d. Hepatocyt.

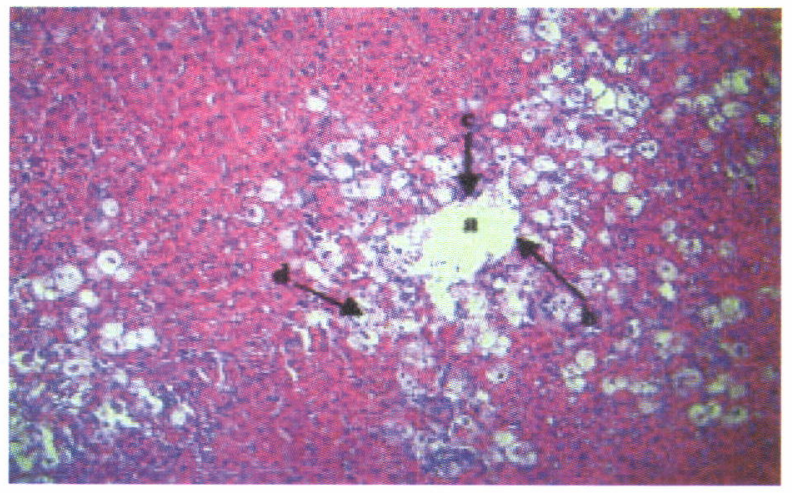

Gambar 6. Histopatologi hati tikus kelompok K3 (ekstrak air rumput laut dosis 0,162 g/100 g BB).

a. Diameter vena sentralis,

b. Sel endotel vena sentralis,

c. Ada sel-sel darah putih,

d. Hepatosit.

Figure 6. Histopathology of rat liver group K3 (seaweed water extract dose of $0.162 \mathrm{~g} / 100 \mathrm{~g} \mathrm{BW}$ ).
a. Diameter of central vein,
b. Endothel cell of central vein,
c. There was a leucocyt cells,
d. Hepatocyt. 


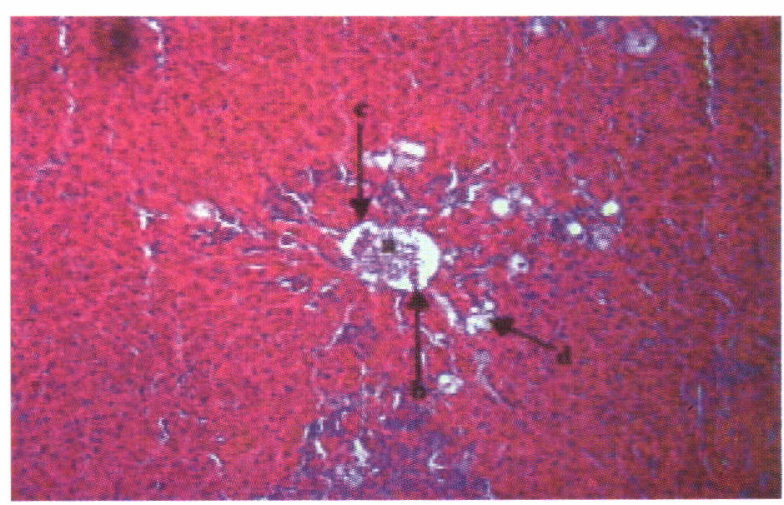

Gambar 7. Histopatologi hati tikus kelompok K4 (ekstrak air rumput laut dosis 0,324 g/100 g BB).
a. Diameter vena sentralis,
b. Sel endotel vena sentralis,
c. Ada sel-sel darah putih
d. Hepatosit.

Figure 7. Histopathology of rat liver group K4 (seaweed water extract dose of $0.324 \mathrm{~g} / 100 \mathrm{~g} \mathrm{BW}$ ).
a. Diameter of central vein,
b. Endothel cell of central vein,
c. There was a leucocyt cells.
d. Hepatocyt.

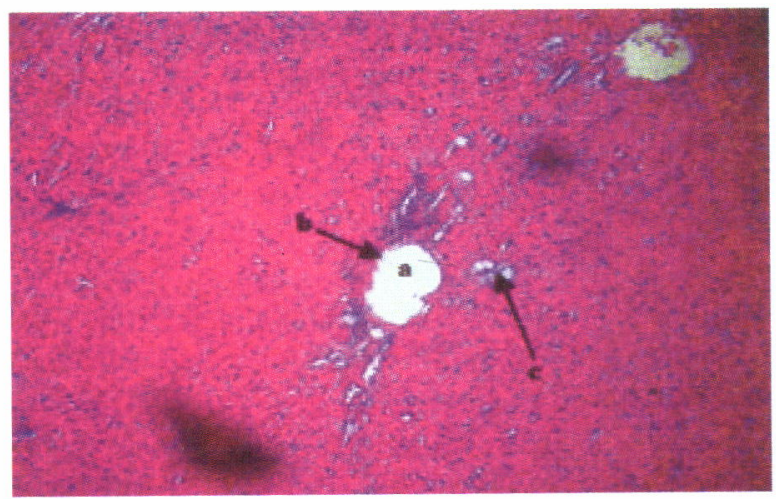

Gambar 8. Histopatologi hati tikus kelompok K5 (ekstrak air rumput laut dosis 0,647 g/100 g BB).
a. Diameter vena sentralis,
b. Sel endotel vena sentralis,
c. Hepatosit.

Figure 8. Histopathology of rat liver group K5 (seaweed water extract dose of $0.647 \mathrm{~g} / 100 \mathrm{~g} \mathrm{BW}$ ).
a. Diameter of central vein,
b. Endothel cell of central vein,
c. Hepatocyt. 


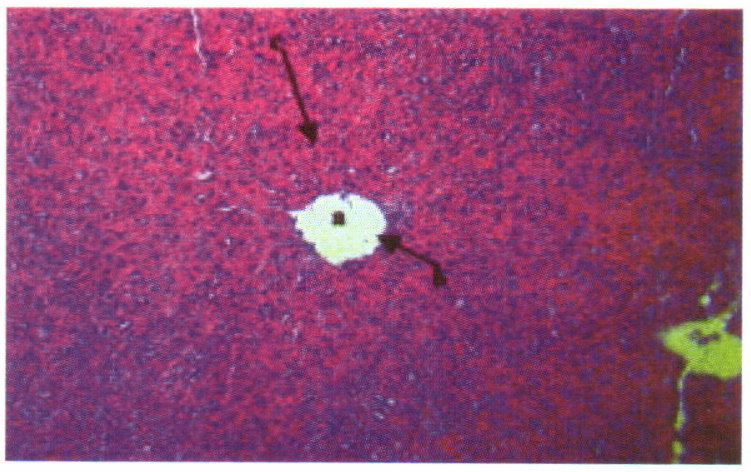

Gambar 9. Histopatologi hati tikus kelompok K6 (kontrol positif, vit. E 2,7 mg/100 g BB).
a. Diameter vena sentralis,
b. Sel endotel vena sentralis,
c. Hepatosit.

Figure 9. Histopathology of rat liver group K6 (positive control, vit E $2.7 \mathrm{mg} / 100 \mathrm{~g} \mathrm{BW}$ ).
a. Diameter of central vein,
b. Endothel cell of central vein,
c. Hepatocyt.

Tabel 7. Gambaran histopatologi hati tikus percobaan

Table 7. Histopathology representation of experimental rat liver

\begin{tabular}{|c|c|c|c|}
\hline Kelompok/Group & & Vena sentralis/Central vein & Hepatosit/Hepatocyt \\
\hline $\begin{array}{c}\text { K1 } \\
\text { Kontrol/Control } \\
\text { Normal/Normal }\end{array}$ & 1 & $\begin{array}{l}\text { Rata-rata diameter vena sentralis } \\
73.716 \mu \mathrm{m} / \text { Mean diameter of central } \\
\text { vein was } 73.716 \mu \mathrm{m} \\
\text { Sel-sel endotel vena sentralis } \\
\text { normal, tidak mengalami kerusakan/ } \\
\text { There was no damage of central } \\
\text { vein endothel cells. }\end{array}$ & $\begin{array}{l}1 \text { Tak terlihat adanya nekrosis pada } \\
\text { sel hepatosit, susunan sel tampak } \\
\text { teratur seperti pita-pita dan di } \\
\text { antaranya terdapat sinus } \\
\text { pembuluh darah/There was no } \\
\text { necrosis on the hepatocyt cells, } \\
\text { the cells were arranged in order } \\
\text { like a bands and there was a } \\
\text { sinus of capillary blood vessels } \\
\text { among the bands. }\end{array}$ \\
\hline $\begin{array}{c}\mathrm{K} 2 \\
\text { Kontrol negatif } \\
\mathrm{CCl}_{4} \text { dengan dosis } \\
55,00 \mathrm{mg} / 100 \mathrm{~g} \mathrm{BB} \\
/ \mathrm{Negative} \mathrm{control} \\
\mathrm{CCl}_{4} \text { with the dose } \\
\text { of } 55.00 \mathrm{mg} / 100 \mathrm{~g} \\
\mathrm{BW}\end{array}$ & 3 & $\begin{array}{l}\text { Rata-rata diameter vena sentralis } \\
90,686 \mu \mathrm{m} / \text { Mean diameter of central } \\
\text { vein was } 90.686 \mu \mathrm{m} \text {. } \\
\text { Sel-sel endotel vena sentralis } \\
\text { mengalami kerusakan dan terjadi } \\
\text { pembekuan darah sehingga ada } \\
\text { pembendungan/There was a } \\
\text { damage of central vein endothel } \\
\text { cells and formed a blood clotting } \\
\text { that blocked the blood circulation. } \\
\text { Di antara sel-sel endotel terjadi } \\
\text { penumpukan/kumpulan sel darah } \\
\text { putih yang menunjukkan adanya } \\
\text { kerusakan jaringan/There was a } \\
\text { gathering of leucocyt among the } \\
\text { endothel cells which represented a } \\
\text { tissue damage. }\end{array}$ & $\begin{array}{l}1 \text { Sel hepatosit mengalami } \\
\text { kerusakan lebih dari } 40 \% \text {; terlihat } \\
\text { dari terjadinya nekrosis dengan } \\
\text { adanya rongga-rongga pada } \\
\text { hepatosit/The damage of } \\
\text { hepathocyt cells was more than } \\
40 \% \text { that was shown from the } \\
\text { necrotics that formed holes in the } \\
\text { hepatocyt. }\end{array}$ \\
\hline
\end{tabular}


Tabel 7. Gambaran histopatologi hati tikus percobaan (lanjutan)

Table 7. Histopathology representation of experimental rat liver (continued)

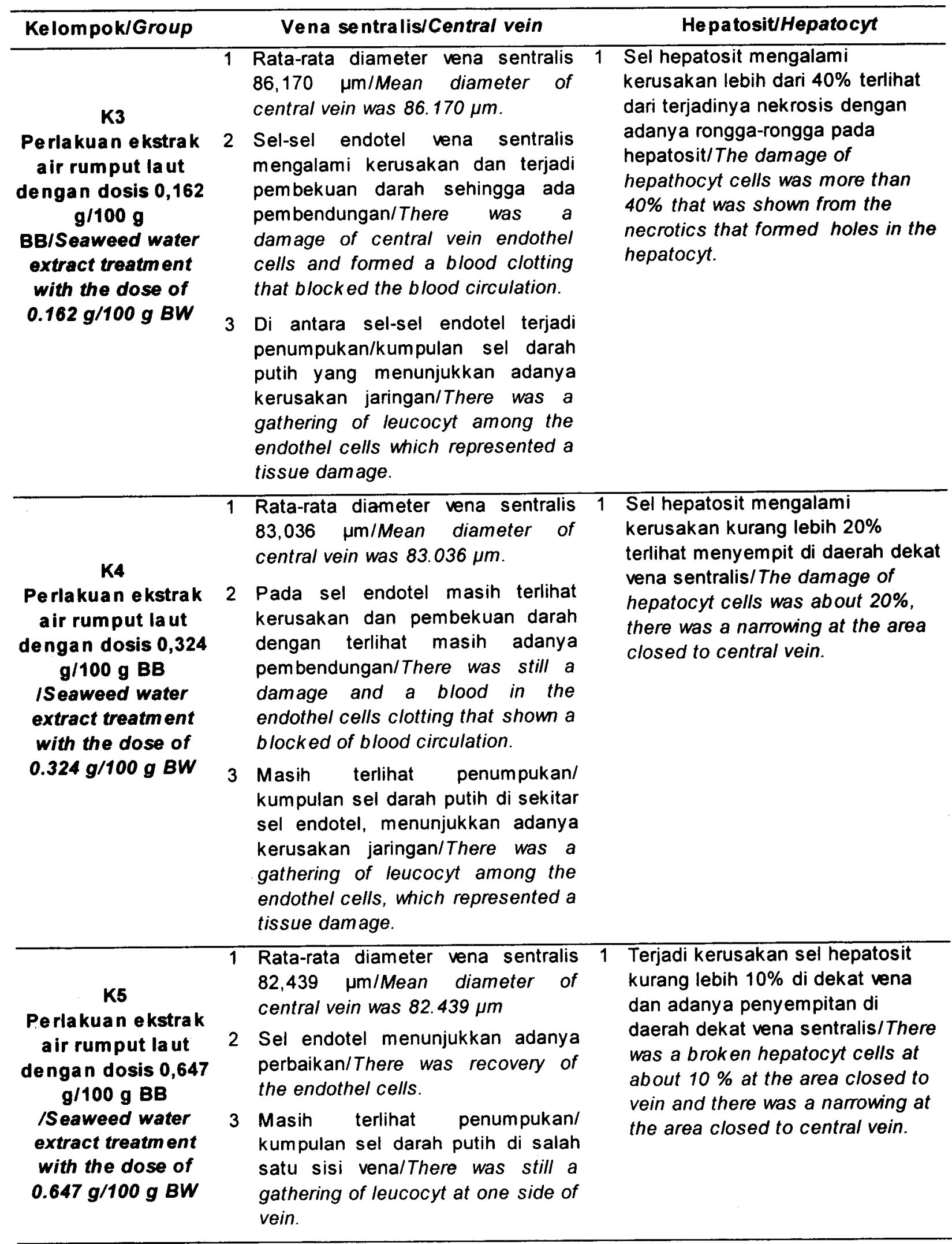


Tabel 7. Gambaran histopatologi hati tikus percobaan (lanjutan)

Table 7. Histopathology representation of experimental rat liver (continued)

\begin{tabular}{|c|c|c|c|}
\hline Kelompok/Group & & Vena sentralis/Central vein & Hepatosit/Hepatocyt \\
\hline $\begin{array}{c}\text { K6 } \\
\text { Kontrol positif, vit. } \\
\text { E dengan dosis } 2,7 \\
\text { mg/100 g BB } \\
\text { IPositive control, } \\
\text { vit. E with the dose } \\
\text { of } 2.7 \mathrm{mg} / 100 \mathrm{~g} \\
B W\end{array}$ & 1 & $\begin{array}{l}\text { Rata-rata diameter vena sentralis } \\
81,003 \mu \mathrm{m} / \text { Mean diameter of } \\
\text { central vein was } 81.003 \mu \mathrm{m} \text {. } \\
\text { Sel endotel menunjukkan adanya } \\
\text { perbaikan/There was recovery of } \\
\text { the endothel cells. } \\
\text { Masih terlihat sedikit kumpulan sel } \\
\text { darah putih di salah satu sisi vena/ } \\
\text { There was still a small gathering of } \\
\text { leucocyt at one side of vein. }\end{array}$ & $\begin{array}{l}\text { Tidak terlihat adanya nekrosis } \\
\text { pada sel hepatosit, susunan sel } \\
\text { tampak teratur seperti pita-pita } \\
\text { dan di antara pita-pita terdapat } \\
\text { sinus pembuluh darah/There was } \\
\text { no necrosis on the hepatocyt } \\
\text { cells, the cells were arranged in } \\
\text { order like bands and there was } \\
\text { sinus of capillary blood vessels } \\
\text { among the bands. }\end{array}$ \\
\hline
\end{tabular}

yang tidak mendapatkan pemberian antioksidan, mengalami kerusakan yang paling parah karena serangan radikal bebas. Kelompok K3, K4, dan K5 (perlakuan ekstrak air rumput laut S. crassifolium) mengalami kerusakan yang tidak parah karena mendapat asupan zat antioksidan. Makin meningkat pemberian dosis ekstrak air rumput laut menunjukkan tingkat kerusakan sel hati yang makin menurun, atau dengan kata lain tingkat perbaikan kerusakan sel hati yang makin meningkat.

\section{KESIMPULAN}

Berdasarkan hasil pengamatan yang dilakukan tentang pengaruh pemberian larutan ekstrak air rumput laut Sargassum crassifolium terhadap kadar MDA plasma darah, kadar SOD sel darah merah, dan gambaran histopatologi hati tikus yang mendapat induksi $\mathrm{CCl}_{4}$, dapat disimpulkan bahwa:

1. Ekstrak air rumput laut Sargassum crasifolium termasuk bahan dengan toksisitas rendah.

2. Pemberian ekstrak air rumput laut $S$. crassifolium dosis $0,324 \mathrm{~g} / 100 \mathrm{~g}$ BB dan 0,647 $\mathrm{g} / 100 \mathrm{~g}$ BB dapat menghambat peningkatan kadar MDA plasma dan mencegah penurunan kadar SOD sel darah merah. Pemberian ekstrak air rumput laut $S$. crassifolium dosis $0,647 \mathrm{~g} /$ $100 \mathrm{~g} \mathrm{BB}$ memberikan efek sebagai antioksidan yang sama kuat dengan vitamin $\mathrm{E}$ dosis $2,7 \mathrm{mg} /$ $100 \mathrm{~g} \mathrm{BB}$.

3. Pemberian ekstrak air rumput laut $S$. crassifolium dosis $0,162 \mathrm{~g} / 100 \mathrm{~g} \mathrm{BB}, 0,324 \mathrm{~g} /$ $100 \mathrm{~g} \mathrm{BB}$, dan $0,647 \mathrm{~g} / 100 \mathrm{~g} \mathrm{BB}$ dapat mencegah kerusakan hati. Pemberian infus $S$. crassifolium dosis $0,324 \mathrm{~g} / 100 \mathrm{~g} \mathrm{BB}$ dan $0,647 \mathrm{~g} / 100 \mathrm{~g} \mathrm{BB}$ memberikan efek yang sama kuat dengan vitamin $\mathrm{E}$ dosis $2,7 \mathrm{mg} / 100 \mathrm{~g} \mathrm{BB}$, untuk mencegah kerusakan hati dan membantu proses perbaikan kerusakan sel hati akibat induksi $\mathrm{CCl}_{4}$ (berperan sebagai hepatoprotektor).

\section{UCAPAN TERIMA KASIH}

Ucapan terima kasih disampaikan kepada Dr. Dadang Kusmana di Laboratorium Reproduksi Biologi Perkembangan dan Mikroteknik, Jurusan Biologi, F MIPA, Universitas Indonesia, atas bantuannya dalam supervisi histopatologi.

\section{DAFTAR PUSTAKA}

Atmaja, W.S., Kadi, A., Satari, R., dan Sulistijo. 1996. Pengenalan Jenis-jenis Rumput Laut Indonesia. Pusat Penelitian dan Pengembangan OseanologiLIPI, Jakarta. 6 pp.

Chapman, V.J. and Chapman D.J. 1980. Seaweeds and their uses. $3^{\text {rd }}$ ed. Chapman and Hall, London. p. 194225.

Dadan, R. 2001. Aktifitas daya tangkap radikal polifenol dalam daun teh. Majalah Farmasi Indonesia. 12(1): 53-58.

Franciscus, D.S. 1989. Radikal bebas dan iskemia. Cermin Dunia Kedokteran. p. 26-28

Gleason, M.N. 1969. Clinical Toxicology of Commercial Product. William and Wilkins, Baltimore. p. 3-4

Harmita dan Radji, M. 2004. Analisis Hayati. Departemen Farmasi-FMIPA-UI, Jakarta. 185 pp.

Jansen, S. 2002. Senyawa polifenol sebagai komponen aktif yang berkhasiat dalam teh. Majalah Kedokteran Indonesia 52(10): 361-364 
Khotimchenko, Y.S. and Khotimchenko, M.Y., 2004. Healing and preventive effects of calcium alginate on carbon tetrachloride induced liver injury in rats. Marine Drugs. 2: 108-122.

Misra, Hanifi, A., dan Hermanta, T. 1996. Pemeriksaan pendahuluan talus Sargassum $\mathbf{s p}$. dan isolasi steroida. Prosiding Seminar Nasional Hasil Penelitian dalam Bidang Farmasi. p. 496-497.

Suntoro, S.H. 1983. Metode Pewamaan Histologi dan Histokimia. Bhatara Karya Aksara, Jakarta. p. 42-49.

Suptijah, P. 2002. Rumput laut: Prospek dan tantangannya. http/rudyct.tripod.com/sem2_012/ pipih_suptijah.htm. Diakses 30 April 2003.
Weil, C.S. 1952. Tables for convenient calculation of median effective dose $\left(\mathrm{LD}_{50}\right.$ or $\left.E D_{50}\right)$ and instruction in their use. Biometrics. (8): 247-253.

Wikanta, T., Riyadi, A., dan Rahayu, L. 2000. Pengaruh pemberian natrium alginat terhadap penurunan kadar glukosa darah kelinci dengan metode toleransi glukosa oral. Octopus. 4(1): 1-13.

Wikanta, T., Khaeroni, dan Rahayu, L. 2002. Pengaruh pemberian natrium alginat terhadap penurunan kadar glukosa darah tikus. J. Pen. Perik. Ind. 8(6): 45-52.

Wikanta, T., Nasution, R.R., dan Rahayu, L. 2003. Pengaruh pemberian natrium alginat terhadap penurunan kadar kolesterol total dan bobot badan tikus. J. Pen. Perik. Ind. 9(5): 23-32. 
